\title{
Mani, Augustine and the vision of God
}

\begin{tabular}{|c|c|}
\hline \multicolumn{2}{|l|}{$\begin{array}{l}\text { Author: } \\
\text { lain Gardner }\end{array}$} \\
\hline \multicolumn{2}{|c|}{$\begin{array}{l}\text { Affiliations: } \\
{ }^{1} \text { Department of Studies } \\
\text { in Religion, University of } \\
\text { Sydney, Australia }\end{array}$} \\
\hline \multicolumn{2}{|c|}{$\begin{array}{l}{ }^{2} \text { Research Fellow, } \\
\text { Department of Church } \\
\text { History and Polity, University } \\
\text { of Pretoria, South Africa }\end{array}$} \\
\hline \multicolumn{2}{|c|}{$\begin{array}{l}\text { Note: } \\
\text { Contribution to 'Augustine } \\
\text { and Manichaean Christianity', } \\
\text { the First South African } \\
\text { Symposium on Augustine of } \\
\text { Hippo, University of Pretoria, } \\
24-26 \text { April 2012. Prof. } \\
\text { Dr lain Gardner is } \\
\text { participating as research } \\
\text { fellow of Prof. Dr Hans } \\
\text { van Oort, Professor } \\
\text { Extraordinarius in the } \\
\text { Department of Church History } \\
\text { and Polity of the Faculty of } \\
\text { Theology at the University of } \\
\text { Pretoria, Pretoria, South Africa. }\end{array}$} \\
\hline \multicolumn{2}{|c|}{$\begin{array}{l}\text { Correspondence to: } \\
\text { lain Gardner }\end{array}$} \\
\hline \multicolumn{2}{|c|}{$\begin{array}{l}\text { Email: } \\
\text { iain.gardner@sydney.edu.au }\end{array}$} \\
\hline \multicolumn{2}{|c|}{$\begin{array}{l}\text { Postal address: } \\
\text { Department of Studies in } \\
\text { Religion, Woolley Building } \\
\text { (A20), University of Sydney, } \\
\text { NSW2006, Australia }\end{array}$} \\
\hline \multicolumn{2}{|c|}{$\begin{array}{l}\text { Dates: } \\
\text { Received: } 31 \text { Oct. } 2012 \\
\text { Accepted: } 10 \text { Jan. } 2013 \\
\text { Published: } 10 \text { Apr. } 2013\end{array}$} \\
\hline \multicolumn{2}{|c|}{$\begin{array}{l}\text { How to cite this article: } \\
\text { Gardner, I., 2013, 'Mani, } \\
\text { Augustine and the vision of } \\
\text { God', HTS Teologiese Studies/ } \\
\text { Theological Studies 69(1), } \\
\text { Art. \#1352, } 6 \text { pages. http:// } \\
\text { dx.doi.org/10.4102/hts. } \\
\text { v69i1.1352 }\end{array}$} \\
\hline \multicolumn{2}{|c|}{$\begin{array}{l}\text { Copyright: } \\
\text { (C) 2013. The Authors. } \\
\text { Licensee: AOSIS } \\
\text { OpenJournals. This work } \\
\text { is licensed under the } \\
\text { Creative Commons } \\
\text { Attribution License. }\end{array}$} \\
\hline Read onine: & \\
\hline 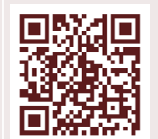 & $\begin{array}{l}\text { Scan this QR } \\
\text { code with your } \\
\text { smart phone or } \\
\text { mobile device } \\
\text { to read online. }\end{array}$ \\
\hline
\end{tabular}

The recovery of the text of the Manichaean daily prayers provides an opportunity to consider how their recitation and practice may have influenced the young Augustine. It is argued that the prayers focused the mental and indeed physical gaze of the believer on the manifestation of God in this present reality, and through that upon the transcendent eternal world of future hope. If one accepts that Augustine as a Manichaean catechumen would have partaken in this most basic of the community's religious duties then one must consider what effect this could have had on the development of his own striking and influential teachings about the vision of God. The article discusses evident allusions to this Manichaean practice in Augustine's writings, and suggests that its influence continued through his later life despite his disavowal of his former faith. In particular, attention is drawn to similarities between the Manichaean 'new aeon' and the 'heaven of heaven' in Augustine's writings, where the pure of heart can look forward to unmediated contemplation of God.

\section{Introduction}

This article was born of a series of happy coincidences. There were, firstly, those that led to the realisation that the text of the Manichaean daily prayers was by no means lost to modern scholars, but preserved in multiple copies from very different times and places of the community's history. Further, when this realisation was first published in the recent Festschrift for Johannes Van Oort (Gardner 2011a:245-262), there were other articles in that volume that provided useful correlations to my line of thought. I think particularly, though not exclusively, of Nils Arne Pedersen's discussion of the veil that hides the face of God, the Father of Greatness (Pedersen 2011:229-234). And then, further, I find an impressive and fertile new interest in the connections between Augustine and his (once) Manichaean heritage, evidenced in the recent work of many of the scholars gathered here at the University of Pretoria. ${ }^{1}$ I am indebted to all of the above in this article, the theme of which is that saying of the saviour (to use Mani's preferred nomenclature): 'Blessed are the pure in heart, for they shall see God' (Mt 5:8).

\section{Main Text}

When we look at the daily prayers we find a formal ritual punctuating the day and night at set hours, and accompanied by a specific set of actions. These were a fundamental building block for the community's practice, providing a crucial unity of endeavour and a focus that belies the fragmentation of languages and cultures that have drawn so much scholarly attention. When, in the past, it was supposed that al-Nadim's account ${ }^{2}$ of the prayers was the only detailed source available, there was always the concern that what he recounted was somehow an adaptation to Muslim practice in the Abbasid Empire. However, whilst some questions do remain about details of the times of day and the physical actions of prostration, we now know that the (incomplete) text he provided in Arabic is fundamentally the same as that utilised in 4th century Egypt or medieval Sogdia. There is no reason to suppose that it differed from that practised in Roman North Africa, so that - if Augustine's 'Manichaean' experience has any meaning - it must have been the same as known to and undertaken by the later Catholic bishop in his youth. This is what he tells directly, maintaining (one might observe) a studious distance in his account:

In the daytime they offer their prayers towards the sun, wherever it goes in its orbit; at night, they offer them towards the moon, if it appears; if it does not, they direct them towards the north, by which the sun, when it has set, returns to the east. They stand while praying. (Augustine, De haeresibus XLVI.18, in Gardner \& Lieu 2004:191)

There were ten prayers, the first addressed to the supreme God, the Father of the Lights; and then descending down the hierarchy of being (as it were) through the emanations, Christ, the angels

1.See the major overview of the topic by J. Van Oort (2010:505-546). Amongst many other important studies, note especially J.D. BeDuhn (2010, the first of a projected three volumes); and the extended review by J. Van Oort (2011:543-567).

2.Al-Nadim's text is best known to anglophone readers in the translation of Dodge (1970:790-791); but see now Reeves (2011:210-211). For detailed discussion of the prayers and the sources see Gardner (2011a:245-262), and then my more extended treatment of the same (Gardner 2011b:79-99). I do not intend to repeat all this material again here. 
and finally to the community of the righteous. In conclusion, the practitioner asks for help and favour from all the ones who have been worshipped and named; in order to be freed from pain and rebirth, and at the last to attain the peace and eternal life of the realm of light.

My concern here is not to discuss the content of the text of the prayers. Rather, I want to focus on the required moral state of the subject, the one who prays, and on the object that is addressed, the sun by day or moon by night. It is specified that the practitioner must pray with 'a pure heart and a truthful tongue.' The phrase is (obviously) rendered slightly differently in the various languages in which we find it preserved, including both Sogdian and Arabic. But it is so characteristic that we can even recognise it in the Uighur confessional: ${ }^{3}$

There is a rule to direct four prayers to the God Äzrua, the God of the sun and the moon, the fivefold God and the buddhas; with complete attention and an earnest heart, daily.

I presume that the original text of the prayers was in Aramaic, and it is interesting to see how the Greek version ${ }^{4}$ gives two slightly different translations. At the start of the first

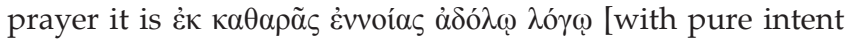
and honest speech]; whilst in the final ritual instructions

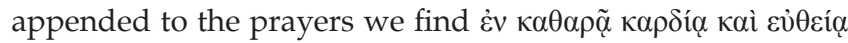
$\gamma \lambda \omega \sigma \sigma \eta$ [with a pure heart and forthright tongue]. It is the latter that most clearly directs us to what must be the original

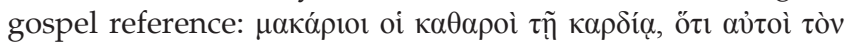

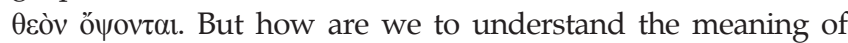
this? It is certain, as we shall see, that the practitioner did not suppose that they were gazing directly upon God the Father, because one of the crucial tenets of Manichaean theology was that the Father is hidden from time and the cosmos. But, at the same time, it is more than an anticipation of a future unveiling. One of the most characteristic themes of Mani's teaching was that truth is not something heard or believed by report, or proved by discursive reasoning. It is seen by the eyes, just as the light filling the moon is manifest in the night sky. He promised his followers: 'Look, you have seen everything by an eye-revelation. You do not lack anything from the mysteries of the wisdom of God' (P. Kellis VI Copt. 54, 8-11) (see Gardner 2007).

The matter is most succinctly put by the Manichaean bishop Faustus when he insists that God dwells in the light: the Father in the light inaccessible (1 Tm 6:16), but the Son in the visible sun and moon (cf. Augustinus Contra Faustum Manichaeum XX, 2). Let us turn now to those objects of prayer. In the first place the sun and the moon are 'ships' (Coptic jai or Greek $\pi \lambda$ oĩov) (see the references in Clackson et al. 1998). The symbolism is ancient, of course, in that they traverse the sky. But for the Manichaean community there were layers of very specific meaning. The light-soul that ascends, whether our very own or that refined from this 'mixed' world that is the cosmos, fills up the vessel of the moon, before it is transferred to the sun and thence to the 'new aeon' (to which we will return later). This process is

3.Xuastvanift X, i; quoted from Klimkeit (1993:303). J.P. Asmussen (1975:74) translates: '... in simplicity (sincerity) and with a pure heart.'

4.P. Kellis VI Gr. 98; in Gardner (2007). visible: not only can we see these vessels that ferry the soul, but the divine living soul is itself apparent in that it is made up of the five light-elements. Thus the moon is specifically the 'ship of living water' and the sun 'the ship of living fire'. The process of the waxing and waning of the moon was a very obvious demonstration of the supposed truth of this teaching, whilst the constant plenitude of the sun was a mystery that Mani needed to discuss. ${ }^{5}$

However, the sun and moon did not only carry the ascending light, they were also dwellings (sometimes thrones or palaces) for the emanated gods at work in the cosmos, undertaking the processes involved in the redemption of the light and defeat of the darkness and its powers. ${ }^{6}$ Various lists occur in the Manichaean (and anti-Manichaean) texts to locate the different gods according to their homes, and this is what Faustus meant when he talked about the 'Son' in the visible sun and the moon. For example, the polemical Acts of Archelaus not only discusses the process of ferrying the souls, and the waxing and waning of the moon (Acts of Archelaus 26, 6-7); but also places Jesus 'in the little ship' and so on (Acts of Archelaus 31, 6). Indeed, the association of Jesus (here in his aspect as the salvific god 'Jesus Splendour') and the moon was so strong, that in a wonderful fragment of Manichaean mission history preserved in Sogdian we can read:?

Thereupon, on the fourteenth (i.e. of the lunar month when the moon was full), Gabriab and his assistants stood in supplication and prayer. And near nightfall when Jesus rose, Gabriab stood before Jesus in prayer and spoke thus to him ...

However, one should note that there was a duality in the conception of the figure of Jesus, so that he could be associated both with the principal god of descent (the First Man) and with that of salvation (the Third Ambassador), both with female Virgin of Light in the moon and with the male in the sun. In the Kephalaia it is explained that Jesus descended through the ship of the day (the primary abode of the Ambassador) and the ship of the night (the primary abode of the First Man) before he appeared in the world. ${ }^{8}$ Thus we can understand why Faustus placed the 'Son' in both vessels.

There is a further aspect to consider. The sun and moon were vessels and palaces, but they were also gates and portals to the transcendent realm. This is made clear in many places, but of particular importance is the citation from Mani himself preserved by al-Biruni: ${ }^{9}$

The other religious bodies blame us because we worship sun and moon, and represent them as an image. But they do not know their real natures; they do not know that the sun and moon are

5.For a compendium of Manichaean teachings on these matters start with Kephalaion 65: 'Concerning the sun'.

6.There is a wonderful image of the gods seated on their thrones in the 'ships of the day and the night', id est, the sun and the moon, in the recently identified Chinese cosmogonic scroll; cf. Yoshida (2010:1-34 [plate 1]).

7.Cf. Henning (1945:155). Perhaps one should also reference the very interesting quote from the Bhavishya Purana: '... by meditation he should worship Isa, who is see the discussion and references in Scott (2007:107-130 [this quoted on p. 119]).

8.For example, Kephalaion 8: 'Concerning the fourteen vehicles that Jesus has boarded

9.Translation following Sachau (1910:169); compare Reeves (2011:127) 
our path, the door whence we march forth into the world of our existence (into heaven), as this has been declared by Jesus.

The Kephalaia again discusses this point: The sun is the gate of life to the great aeon of light, and it is for this reason that Satan placed an exclusionary judgement on it saying that Whoever will worship it can die (Dt 17:2-5). ${ }^{10}$ I think that we must understand a further visual aspect here: to look at the sun (although in truth our bodily eyes cannot) is to gaze through an open space in the material heaven of this world into that other realm. One is reminded of meditation techniques where one focuses on a disk, if that is not too fanciful an analogy.

So, we can unpack various dimensions to the promise that the pure of heart shall see God. In directing one's gaze at the sun and moon one sees the visible manifestation of the purified 'living soul' in its ascent, one sees the gods in their palaces, and one can even try to look through into the transcendent world of blazing light. But God the Father remains inaccessible.

Before we turn to the eschatological dimension of what happens when the soul reaches that other realm (termed 'the new aeon'), it is worthwhile to emphasise again the visual reality of Mani's vision. Here one enters the confusing realm of what is often termed 'mythology', but that is to miss the point. There is a story in the appendix to the second volume of Kephalaia, ${ }^{11}$ where a series of vignettes are presented from Mani's last journeys as he visits and speaks to his communities of elect and catechumens, prior to the final trials and imprisonment and death. The apostle travels when the moon ('the enlightener of the night') is in eclipse, in order to greet his disciples in another city. When he arrives they ask him to explain about this event. What comes next is unusual. In the texts Mani always announces that he is the one to explain such and such a matter. But not on this occasion. Rather, we read that 'he did not want to have to tell them.' Inevitably, the disciples beseech and entreat, and will not take this refusal; so at last the apostle must explain. Unfortunately, the exact details of what he says are largely lost in a badly destroyed passage, but it will have been some terrible narrative of treachery and attack by the forces of darkness against the vulnerability and suffering of the light. But what is really interesting is the word which I have glossed above as meaning an eclipse. It is a relatively rare Coptic term $e b \bar{e}$ which is generally used with the verb eire and translated something like 'to make obscure'. However, the word is certainly linked to the more common term hèbe meaning 'grief' or 'mourning','12 and thus I think we can consider a translation for $e b \bar{e}$ as 'veil'. This is strongly suggested by this unpublished Kephalaia passage where it

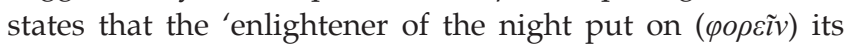
veil $(e b \bar{e})^{\prime}$.

\section{See Kephalaia 158, 26-159, 4.}

11.This appendix (and the entire second volume) is in the process of being edited by the team of I. Gardner, J. BeDuhn and P. Dilley. I draw here from my first reading of the passage, which can be found in the facsimile edition published by Giversen (1986: plate 310).

12.See the entries and references in Crum (1939:52b, 655a-b).
We can take this digression a little further and reference here the valuable description of Manichaean cosmological teachings by the sixth-century Neoplatonist Simplicius. ${ }^{13}$ Apparently, eclipses are due to veils $\left(\pi \alpha \rho \alpha \pi \varepsilon \varepsilon^{\prime} \alpha \sigma \mu \alpha\right)$ thrown up by the 'light bringers' to shield themselves from the tumult and disorder caused by the evil rulers who are chained in the heavens. The striking thing about Simplicius's discussion based directly (he says) on the explanation of one of 'their wise men' (бофós) - is that the Manichaeans did not regard these teachings as myths or as having any other meaning. This is an important and pertinent remark, and true to the authentic voice of Mani.

Of course, this very issue about the cause of eclipses played an important role in the public history of the religion. In the Confessions $(\mathrm{V}, 3)$, Augustine famously recounts when the renowned Manichaean bishop Faustus came to Carthage during his twenty-ninth year. He details his growing dissatisfaction with that community through contrasting their 'lengthy fables' with the ability of those he terms philosophers to predict an eclipse, this by what we might call the empirical study of the natural world. Augustine explains how he searched the works of Mani, who in his 'voluminous folly' had written many books on such topics; but he could find nothing in them to compare with the rational theories established by a study of mathematics (the practice of calculations). As a result, he put his perplexities to Faustus $(\mathrm{V}, 7)$ and was disappointed. Augustine then departed for Rome.

The story is well-known, ${ }^{14}$ but we should note how Augustine states that the Manichaeans 'thought themselves to be exalted amongst the stars and shining. ${ }^{15}$ With the use of Romans 1:25 he can explain how they have exchanged truth for a lie, to worship the creature rather than the creator. It is possible to read in this passage a guarded allusion to the daily prayers, ${ }^{16}$ although that is not in itself necessary. We shall return to Augustine later, to the question of whether God can be seen by bodily eyes; but, first, we must ascend beyond the heavens, through the portal of the sun and into that other realm called the 'new aeon'.

In the Manichaean cosmology, the demiurge (the 'Living Spirit' or 'Father of Life') fabricates the cosmos out of the bodies of those evil forces who had first attacked the Primal Man and consumed his 'five sons' (i.e., the divine 'living soul'). Thus the design of creation is good, as a machine for the purification of light out of matter, although its substance is a mixture of the divine and the demonic. We must note that

13.Simplicius, in Epicteti encheiridion 27 (treatise 35). See now Lieu and Sheldon (2011:217-228 [on p. 223]).

14. Although it has been discussed by many scholars, see especially Ferrari (1973:263276). For a summary on Manichaean astrology see Pettipiece (2009:62-68); and, further, Beck (1987:193-196). One wonders if this dreadful matter of eclipses might be related to the terrible celestial dragon, on which see also Mastrocinque (2005:162).

15.Augustine, Confessiones V, 3 (5): 'et putant se excelsos esse cum sideribus et lucidos.'

16.See Augustine's parallel earlier comment at Confessiones III, 6 (10): 'et illa erant fercula, in quibus mihi esurienti te inferebatur sol et luna, pulchra opera tua, sed tamen opera tua, non tu, nec ipsa prima. priora enim spiritalia opera tua quam ista corporea quamvis lucida et caelestia.' 
the Living Spirit is the third out of a series of gods of creation, the purpose of this second emanation of divinities. ${ }^{17}$ The first of the series is the Beloved of the Lights, whose role is as a custodian of the kingdom of light. The second is the Great Builder, and it is he who constructs the 'new aeon'. What is important about this sequence, is that we can identify three separate realms: (1) the eternal kingdom of light, without beginning and where the Father of Greatness dwells; (2) the new aeon, which we can understand as the heaven of our own existence, that is our destination after death and the ascent through the portals of the moon and sun; (3) the physical cosmos of time and space in which we live at present.

Thus, the new aeon is specifically constructed for the time of mixture. There the victorious rule, with their king the Primal Man (as the first to be delivered from the abyss of death). It is a realm that is created, which came into being at a certain point, and which will also have an end. One might ask: why does the liberated soul not simply ascend to the Father and the eternal kingdom? The answer is a fundamental feature of Manichaean doctrine, that is, that the Father must be kept separate from the realm of conflict, from time and space which are the arena in which evil will be defeated. Thus, the Father is 'a hidden one', this being one of the primary and defining characteristics of Manichaean theology. ${ }^{18}$

If we turn now to eschatology and the end of all things, the logic becomes clear. First this cosmos will be destroyed in the 'great fire' and will collapse in on itself. Once all the light that can be redeemed has ascended, the remaining dregs of matter and its powers will be buried and sealed, male and female separated so that they can never again multiply and challenge the light. It is only then that, finally, the Father will reveal his image to the victorious souls in the new aeon. This future hope, and the crucial duality here between the eternal kingdom and the new aeon, is clearly described in one of the best preserved passages available to us: ${ }^{19}$

Also, after these things the aeons [... the Father of] Greatness. He can give to them what they [beseech of him]. He can give the grace to his fighters, they whom he [sent] to the contest with the darkness. The veils will be rolled back and gathered, and he unveils to them his image! The entire light will be immersed in him! They will go in to the treasury. They will also come forth from him in glory ... king, in the two kingdoms. On the one hand: the King of the aeons of the light, he is the Father, the Light King ... On the other hand: the king of the new aeon is the First Man ...

N.A. Pedersen (2011) has recently published a detailed discussion about the drawing back of the veil and revelation of the image of the Father. ${ }^{20}$ He begins with the telling passage

17.The ordering of the various gods was a complicated matter for Manichaean scholasticism, and it is not necessary to undertake a detailed account here. A classic description can be found in Kephalaion 7, although even that needs amplification for a full understanding. For the work of the Living Spirit start with Kephalaion 32.

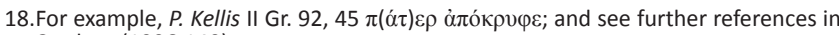
Gardner (1996:140).

19.From the conclusion of The Sermon of the Great War in Polotsky (1934:41, 11-20).

20.Detailed references to most of the issues discussed here will be found there. It will be apparent that I do not agree with his view that 'collective eschatology corresponds to the individual eschatology' (Pedersen 2011:230), that is, that the corresponds to the individual eschatology' (Pedersen 2011:230), that is, that the
individual soul after death will see the image of the Father. Although it is sometimes expressed like this, especially in hymnic texts, I believe that these are intended as poetic anticipation or foreshortening of what will be experienced at the (true) end. poetic anticipation or foreshortening of what will be experienced at the (true) end.
To suppose otherwise is to remove the entire rationale for the new aeon, and the To suppose otherwise is to remove the entire rationale for the
processes of creation and collapse that I have described above. from Augustine's friend Euodius of Uzala: '[God the Father] has a veil (velum) before himself to soothe his pain, so that he should not see the corruption of his own part' (Evodius de Fide contra Manichaeos, 13). This is ascribed to the first book of Mani's Treasure (of Life). What is especially interesting about Pedersen's article is the way that he explores 'the possible religio-historical roots in Judaism of the two themes: (a) the veil that covered the Father and (b) the revelation of his image' (Pedersen 2011:231). As he points out, the Latin word velum is used as a loan word (ouelon in the Coptic texts, via the Greek oviñ $\lambda$ ov. He then tracks the idea back into Jewish tradition, focusing especially on 'Merkabah mysticism' and its goal to see God in the heavenly throne room. However, Pedersen suggests that there is a clear difference between Judaism and Manichaeism, in that in the former the veil is there to protect outsiders (who will die if they see God), whilst in the latter - following Evodius's testimony here - the function is to prevent the Father from seeing the suffering of those on the other side. One should note that the same sort of motive could be supposed regarding the veil in Simplicius's description of eclipses. Finally, Pedersen turns to his second theme of the revelation of the Father's image (Greek/Coptic sikẃv) or face (Coptic ho). He draws our attention to both Christian and Jewish tradition, noting

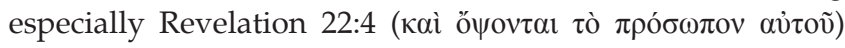
and Matthew 5:8.

To summarise the Manichaean doctrine and practice: in life the pure of heart will train their gaze upon the gods enthroned in the sun and moon. These 'palaces' are visible 'ships' bright with their cargo of redeemed light, and also (to think about it in a slightly different way) they are open 'gates' through which one can look - if one's mortal eyes are able - directly into the heavenly world. But that new aeon is not itself the realm of the Father. Rather, there the Primal Man rules as first of the redeemed; ${ }^{21}$ and it is not until the process of redemption is finalised, and the enemy completely overcome and rendered sterile - only then can the victorious fighters return to the Father from where they first departed.

Thus, we can say that the Manichaean teaching (in brief, and following Faustus's pithy summary) is that God dwells in the light: the Son in the visible, but the Father in what is for now inaccessible. What of Augustine? In the famous passage from Confessions III he reveals his intimate knowledge of their teachings, as he attempts not just to attack but to communicate with them. ${ }^{22}$ I have previously argued that in the following well-known words Augustine appears to parody the fundamental theme of the Manichaean daily prayers ('... with a pure heart and a truthful tongue'), the phrase he will himself have recited repeatedly during his years as an auditor: ${ }^{23}$

21.On the Jewish heritage to the Manichaean narrative about the Primal Man, culminating in his enthronement in the 'age to come', see Smagina (2011:201216).

22.See especially the discussion by Kotzé (2008:187-200); and, as example, that by Mikkelsen (2011:419-425). For a succinct summary of discussion from antiquity to the present about the question of Manichaean influences on Augustine, see to the present about the question of Manichaean influences on Augustine, see
Van Oort (2010, section 5 [pp. 541-545]). Perhaps the most telling theme of $J$. BeDuhn's recent monograph (2010) is to evidence how much Augustine kept with him in his daily practice all his life.

23.Augustine, Confessiones III, 6 (10); see further the discussion in Gardner (2011b). 
... fell among men mad with pride, extremely carnal and talkative, in whose mouths were the snares of the devil, smeared with a sticky mixture of the syllables of your name and that of our lord Jesus Christ and of the Paraclete our comforter, the holy spirit. These names never left their lips, but were no more than empty sound and the rattling of the tongue as their hearts were devoid of any truth whatsoever (haec nomina non recedebant de ore eorum, sed tenus sono et strepitu linguae; ceterum cor inane veri). They kept saying: 'Truth, truth'; and they had a lot to tell me about it, but truth was never in them.

Scholars have sometimes been misled by the extended 'culinary metaphor'24 that follows as Augustine seeks to discredit Manichaean beliefs about the divine nature of the sun and the moon. He is not talking about Manichaean food rituals, but rather the daily regimen or 'diet' of the prayers. The metaphor needs to be read in terms of the fundamental theme of the Confessions, our desperate hunger and thirst for God. If the sun and moon were served up on 'dishes' (fercula), ${ }^{25}$ to feed repeatedly on such hallucinations is to become ever more hungry.

We can continue this 'Manichaean reading' of Augustine's great work with the renowned episode at Ostia in Book IX ${ }^{26}$ It is here, carefully structured and placed within the narrative, that he illustrates what can truly be known and 'seen' of God in this life. As is very well-known, Augustine purports to recount a joint experience of his mother Monica and himself (Chadwick 1991): $:^{27}$

Step by step we climbed beyond all corporeal objects and the heaven itself, where sun, moon, and stars shed light on the earth. We ascended even further by internal reflection and dialogue and wonder at your works, and we entered into our own minds. We moved up beyond them ...

The formal patterning of the ascent is obvious, together with its philosophical framework: bodily senses $>$ corporeal objects $>$ heavens $>$ mind $>$ eternity. The sun and moon are listed; but they are categorised with the stars (a strikingly non-Manichaean turn), and all the heavenly bodies are given a firm, neutral place in God's creation. The summit experience emphasises how limited is the soul's association with God ('... we touched it in some small degree by a moment of total concentration of the heart'). This is 'the first fruits of the spirit' ( $\operatorname{Rm} 8: 23)$; but contemplation is inherently eschatological and cannot be realised by the embodied soul, only actualised after death. What can be 'seen' of God in life

24.See the excellent analysis by Kotzé (2008:194-195). For reading this as a reference to food rituals, Kotzé (2008, n. 20); also, for example, Mikkelsen (2011:420). However, this would make no proper sense. As an auditor, eating and drinking were occasions for sin and confession. The ritual meal was necessarily reserved for the elect, as it was sacted redemptive work by which the divine soul was liberate from its entanglement with matter. But, even then, this was nothing to do with the sun and the moon; except in so far as the light would afterwards ascend, fill and pass through these portals to the new aeon.

25.This is how ferculum is usually translated here; but probably Augustine's sense would be better rendered as 'courses', indicating the repeated servings of such ghost food. In any case, Augustine admits, reluctantly, that he did eat of it; which I understand to mean that he took part in the daily prayers. See also Augustine $D e$ vita beata I, 4 .

26. Of course, these topics have been written about in great detail by many scholars. My purpose here is simply to try and integrate them with the discussion made in this article about Manicha to try and integate them with the discussion made in this article about is indebted to Kenny (2005); which study also acknowledges its debt to the classic work of Henry (1938).

27.Augustine, Confessiones IX, 10 (24), translated by Chadwick (1991). is only an anticipation of what will happen when 'we shall see him as he is' (1 Jn 3:2). ${ }^{28}$

Augustine returned to the topic of the 'vision of God' in many other writings. There is, for example, the lengthy discussion of the three different types of vision in The Literal Meaning of Genesis XII. These are 'bodily', 'spiritual' and 'intellectual'. The last is the most excellent, because it is the sort used in the contemplation of God. It is the vision of intelligible things with the 'eyes of the mind'. It is a kind of rapture and a product of grace. In an obvious way this provides a striking contrast to Mani, and evidences Augustine's Platonic turn. For Mani, as we have elaborated earlier, it is what the physical eyes can see that provides the demonstration and indeed authentication of the teaching.

Of particular interest is Letter 147, written circa 413/414 CE as a reply to the noblewoman Paulina who has asked how the invisible God can be seen. ${ }^{29}$ Augustine's response is almost a small book in itself, and here he explicitly discusses Matthew 5:8. Indeed, he starts from this point: we believe God can be seen because we read so in scripture, id est, at this verse (see 147, 3). However, he then proceeds to distinguish bodily sight from the 'gaze of the mind' $(147,4)$. This is elaborated by a quotation from Ambrose (Commentary on the Gospel of Luke), to which Augustine returns repeatedly in his discussion as if to emphasise an authority other than his own in this matter $(147,18$ et al.). God is not seen in a location, but by a clean heart. He is not sought by bodily eyes, nor held by touch, heard by words or perceived by his walk. Later he himself quotes 1 Timothy 6:16, that God 'dwells in inaccessible light where only the clean of heart can approach' $(147,44)$. The matter is perhaps best explained here:

For blessed are the clean of heart because they shall see God, not when he will appear to them like a body at some distance in space but when he will come to them and make his dwelling with them. For in that way they will be filled with the fullness of God, not when they are fully God but when he will come to them and make his dwelling with them. (Teske 2003:147, 154)

This discussion can be supplemented by reference to Letter 92 (Teske 2003). This had been written somewhat earlier (408 $\mathrm{CE})$ to the widow Italica. God is the light of purified minds, not of these bodily eyes $(92,2)$. This is in the time to come, not in the present. But the impious will not see him, as they are neither blessed nor pure of heart $(92,4)$. The letter makes a strong attack on those who say that we will see God with our bodily eyes, whether in this life or in the resurrection body.

\section{Conclusion}

So, for Augustine it is clear that any vision of God is an intellectual act and entirely different to bodily sight. God is not to be located anywhere, nor seen in this life, except as a rare and fleeting anticipation of the future realm, and in 28.Cf. Augustine, Confessiones XIII, 13 (14).

29.Paulina was a Catholic laywoman in North Africa and the wife of Armentarius. I quote throughout from Teske (2003). The text is also known as De videndo Deo. In Retractiones II, 41 Augustine comments that he has written about the same topic Retractiones II, 11 Augustine comments that he has written about the same topic
in The City of God (book XXII). The texts should be compared, together with other in The City of God (book XXII). The texts should be com
relevant passages such as Sermon 52 and Letter 92. 
that case it is an act of grace. But what is that future realm? Augustine calls it the 'heaven of heaven' (caelum caeli), ${ }^{30}$ and it is interesting to see that it is not so dissimilar to the Manichaean new aeon (also called the kingdom of the household of his people'). ${ }^{31}$ This heaven is not within the uncreated Godhead, nor eternal with the Trinity. It is the first creation (Gn 1:1, read with reference to Ps 148:8). ${ }^{32}$ Augustine discusses it in Confessions XII: ${ }^{33}$

... not even that created realm, the 'heaven of heaven', is coeternal with you. Its delight is exclusively in you. In an unfailing purity it satiates its thirst in you. ... I do not find any better name for the Lord's 'heaven of heaven' than your House. There your delight is contemplated without any failure or wandering away to something else. The pure heart enjoys absolute concord and unity in the unshakeable peace of holy spirits, the citizens of your city in the heavens above the visible heavens.

This is the transcendent realm, the house of God or heavenly city. ${ }^{34}$ The caelum caeli is a collective realm of spirits and the homeland of the soul. Although it is outside of time and space, it is nevertheless a created thing. It is here that contemplation can be unmediated and direct, 'face to face', by the pure of heart. It is true that Augustine rejected the Manichaean practice of his youth, but how successful he was in freeing himself from this heritage remains an intriguing and open question. Indeed, for myself reading Augustine on the 'heaven of heaven' has strangely enabled a better understating of the 'new aeon' than I ever had before!

\section{Acknowledgements Competing interests}

The author declares that he has no financial or personal relationship(s) which may have inappropriately influenced him in writing this article.

\section{References}

Asmussen, J.P., 1975, Manichaean literature, Scholars' Facsimiles \& Reprints, New York. Beck, R., 1987, 'The Anabibazontes in the Manichaean Kephalaia', Zeitschrift für Papyrologie und Epigraphik 69, 193-196.

BeDuhn, J.D., 2010, Augustine's Manichaean dilemma: vol. 1: Conversion and apostasy, 373-388 C.E., University of Pennsylvania Press, Philadelphia.

Chadwick, H., 1991, Saint Augustine: Confessions, Oxford University Press, Oxford.

Clackson, S., Hunter, E., Lieu, S.N.C. \& Vermes, M. (eds.), 1998, Dictionary of Manichaean texts: vol. 1: Texts from the Roman Empire, Brepols, Turnhout.

Crum, W.E., 1939, A Coptic Dictionary, Clarendon Press, Oxford.

30.See the discussion by Kenny (2005:113-115).

31.Kephalaia 39, 11. The reference is to the ascent of the victorious Primal Man.

32.Thus Augustine, Confessiones XII, 15 (20).

33.Augustine, Confessiones XII, 11 (12).

34.J. van Oort (1991:212-229) discusses a possible Manichaean background to Augustine's teaching about the 'two cities'. He gathers together a number of interesting references to the heavenly 'city', but unfortunately does this in the context of the 'two kingdoms' without reference to the new aeon. Elaboration of context of the 'two kingdoms' without reference to the new aeon. Elaboration
this detail would, I believe, be productive for further development of the thesis.
Dodge, B., 1970, The Fihrist of al-Nadim, II, Columbia University Press, New York/ London.

Ferrari, L.C., 1973, 'Astronomy and Augustine's break with the Manichees', Revue des Études Augustiniennes 19, 263-276.

Gardner, I., 1996, Kellis literary texts, vol. 1, Oxbow Books, Oxford.

Gardner, I., 2007, Kellis literary texts, vol. 2, Oxbow Books, Oxford.

Gardner, I., 2011a, 'Manichaean ritual practice at Ancient Kellis: A new understanding of the meaning and function of the so-called Prayer of the Emanations', in J. van den Berg, A. Kotzé, T. Nicklas \& M. Scopello (eds.), In search of truth: Augustine, Manichaeism and other Gnosticism: Studies for Johannes Van Oort at sixty, Manichaeism and other Gnosticism: Studies for Johannes Van Oort at sixty,
pp. 245-262, Brill Academic Publishers, Leiden. http://dx.doi.org/10.1163/ pp. 245-262, Brill Academic Publishers,
ej.9789004189973.i-730.71, PMid:21784273

Gardner, I., 2011b, "'With a pure heart and a truthful tongue": The recovery of the text of the Manichaean daily prayers', Journal of Late Antiquity 4, 79-99. http:// dx.doi.org/10.1353/jla.2011.0003

Gardner, I., Alcock, A. \& Funk, W-P. (eds.), 1999, Coptic documentary texts from Kellis, vol. 1, Oxbow Books, Oxford.

Gardner, I. \& S.N.C. Lieu, 2004, Manichaean texts from the Roman Empire, Cambridge University Press, Cambridge. http://dx.doi.org/10.1017/CBO9780511616891

Giversen, S., 1986, The Manichaean Coptic Papyri in the Chester Beatty Library. I. Kephalaia, Patrick Cramer Éditeur, Genève.

Henning, W.B., 1945, 'The Manichaean Fasts', The Journal of the Royal Asiatic Society 77, 146-164. http://dx.doi.org/10.1017/S0035869X00099603

Henry, P., 1938, La vision d'Ostie, J. Vrin, Paris.

Kenny, J.P., 2005, The mysticism of Saint Augustine: Rereading the Confessions, Routledge, New York.

Klimkeit, H-J., 1993, Gnosis on the Silk Road: Gnostic texts from central Asia, Harper Collins, San Francisco.

Kotzé, A., 2008, "The "anti-Manichaean" passage in Confessions 3 and its Manichaean audience', Vigiliae Christianae 62, 187-200. http://dx.doi. Manichaean audience', Vigiliae
org/10.1163/157007208X247665

Lieu, S.N.C. \& Sheldon, J.S., 2011, 'Simplicius on Manichaean cosmogony', in J. van den Berg, A. Kotzé, T. Nicklas, M. Scopello (eds.), In search of truth: Augustine, Manichaeism and other Gnosticism: Studies for Johannes Van Oort at sixty, Manichaeism and other Gnosticism: Studies for Johannes Van Oort at sixty,
pp. 217-228, Brill Academic Publishers, Leiden. http://dx.doi.org/10.1163/ pp. 217-228, Brill Acade
ej.9789004189973.i-730.62

Mastrocinque, A., 2005, From Jewish magic to Gnosticism, Mohr Siebeck, Tübingen.

Mikkelsen, G., 2011, 'Augustine and his sources: The "devil's snares and birdlime" in the mouths of Manichaeans in East and West', in J. van den Berg, A. Kotzé, T. Nicklas \& M. Scopello (eds.), In search of truth: Augustine, Manichaeism and other Gnosticism: Studies for Johannes Van Oort at sixty, pp. 419-425, Brill Academic Publishers, Leiden. http://dx.doi.org/10.1163/ej.9789004189973.i-730.100

Pedersen, N.A., 2011, 'The veil and revelation of the Father of greatness', in J. van den Berg, A. Kotzé, T. Nicklas \& M. Scopello (eds.), In search of truth: Augustine, Manichaeism and other Gnosticism: Studies for Johannes Van Oort at sixty, pp. 229-234, Brill Academic Publishers, Leiden. http://dx.doi.org/10.1163/ ej.9789004189973.i-730.66, PMid:21316194

Pettipiece, T., 2009, Pentadic redaction in the Manichaean Kephalaia, Brill Academic Publishers, Leiden. http://dx.doi.org/10.1163/ej.9789004174368.i-244

Polotsky, H.J. (ed.), 1934, Manichäische Homilien, W. Kohlhammer, Stuttgart.

Polotsky, H.J., Böhlig, A. \& Funk, W-P. (eds.), 194019661999 2000, Kephalaia, W. Kohlhammer, Stuttgart.

Reeves, J.C., 2011, Prolegomena to a history of Islamicate Manichaeism, Equinox Publishing, Sheffield.

Sachau, E.C. (ed.), 1910, Alberuni's India, vol. 1, Trübner, London.

Scott, D., 2007, 'Manichaeism in Bactria: Political patterns and East-West paradigms', Journal of Asian History 41, 107-130.

Smagina, E., 2011, 'The Manichaean cosmogonical myth as a "re-written Bible", in J. van den Berg, A. Kotzé, T. Nicklas \& M. Scopello (eds.), In search of truth: Augustine, Manichaeism and other Gnosticism: Studies for Johannes Van Oort at Augustine, Manichaeism and other Gnosticism: Studies for Johannes Van Oort at
sixty, pp. 201-216, Brill Academic Publishers, Leiden. http://dx.doi.org/10.1163/ ej.9789004189973.i-730.61

Teske, R.J., 2003, The works of St. Augustine: A translation for the twenty-first century: Letters, vol. 2, New City Press, New York.

Van Oort, J., 1991, Jerusalem and Babylon: A study into Augustine's City of God and the sources of his doctrine of the two cities, Brill, Leiden.

Van Oort, J., 2010, 'Manichaean Christians in Augustine's life and work', Church History and Religious Culture 90, 505-546. http://dx.doi.org/10.1163/187124110X545155

Van Oort, J., 2011, 'Augustine's Manichaean dilemma in context', Vigiliae Christianae 65, 543-567. http://dx.doi.org/10.1163/157007211X591830

Yoshida, Y., 2010, 'Cosmogony and church history depicted in the newly discovered Chinese Manichaean paintings', Yamato Bunka 121, 1-34. 